\title{
Synthesis, Crystal Structure, and DNA-Binding Studies of a Nickel(II) Complex with the Bis(2-benzimidazolymethyl)amine Ligand
}

\author{
Huilu Wu, Tao Sun, Ke Li, Bin Liu, Fan Kou, Fei Jia, Jingkun Yuan, and Ying Bai \\ School of Chemical and Biological Engineering, Lanzhou Jiaotong University, Lanzhou 730070, China \\ Correspondence should be addressed to Huilu Wu, wuhuilu@163.com
}

Received 20 May 2011; Revised 7 June 2011; Accepted 8 June 2011

Academic Editor: Santiago Gómez-Ruiz

Copyright (c) 2012 Huilu Wu et al. This is an open access article distributed under the Creative Commons Attribution License, which permits unrestricted use, distribution, and reproduction in any medium, provided the original work is properly cited.

\begin{abstract}
A V-shaped ligand Bis(2-benzimidazolymethyl)amine (bba) and its nickel(II) picrate (pic) complex, with composition $\left[\mathrm{Ni}(\mathrm{bba})_{2}\right](\mathrm{pic})_{2} \cdot 3 \mathrm{MeOH}$, have been synthesized and characterized on the basis of elemental analyses, molar conductivities, IR spectra, and UV/vis measurements. In the complex, the $\mathrm{Ni}$ (II) ion is six-coordinated with a $\mathrm{N}_{2} \mathrm{O}_{4}$ ligand set, resulting in a distorted octahedron coordination geometry. In addition, the DNA-binding properties of the $\mathrm{Ni}$ (II) complex have been investigated by electronic absorption, fluorescence, and viscosity measurements. The experimental results suggest that the nickel(II) complex binds to DNA by partial intercalation binding mode.
\end{abstract}

\section{Introduction}

Binding studies of small molecules to DNA are very important in the development of DNA molecular probes and new therapeutic reagents [1]. Transition metal complexes have attracted considerable attention as catalytic systems for use in the oxidation of organic compounds [2], probes in electrontransfer reactions involving metalloproteins [3], and intercalators with DNA [4]. Numerous biological experiments have demonstrated that DNA is the primary intracellular target of anticancer drugs; interaction between small molecules and DNA can cause damage in cancer cells, blocking the division and resulting in cell death [5-7].

Since the benzimidazole unit is the key-building block for a variety of compounds which have crucial roles in the functions of biologically important molecules, there is a constant and growing interest over the past few years for the synthesis and biological studies of benzimidazole derivatives [8-10]. Since the characterization of urease as a nickel enzyme in 1975, the knowledge of the role of nickel in bioinorganic chemistry has been rapidly expanding [11]. The interaction of $\mathrm{Ni}$ (II) complexes with DNA appears to be mainly dependent on the structure of the ligand exhibiting intercalative behavior [12-14].
In this context, we synthesized and characterized a novel $\mathrm{Ni}$ (II) complex. Moreover, we describe the interaction of the novel Ni(II) complex with DNA using electronic absorption and fluorescence spectroscopy and viscosity measurements.

\section{Experimental}

2.1. Materials and Methods. Calf thymus DNA (CT-DNA) and Ethidium bromide (EB) were purchased from Sigma Chemicals Co. (USA). All chemicals used were of analytical grade. All the experiments involving interaction of the ligand and the complexes with CT-DNA were carried out in doubly distilled water buffer containing $5 \mathrm{mM}$ Tris and $50 \mathrm{mM} \mathrm{NaCl}$ and adjusted to $\mathrm{pH} 7.2$ with hydrochloric acid. A solution of CT-DNA gave a ratio of UV absorbance at 260 and $280 \mathrm{~nm}$ of about 1.8-1.9, indicating that the CT-DNA was sufficiently free of protein [15]. The CT-DNA concentration per nucleotide was determined spectrophotometrically by employing an extinction coefficient of $6600 \mathrm{M}^{-1} \mathrm{~cm}^{-1}$ at $260 \mathrm{~nm}[16]$.

Elemental analyses were performed on Carlo Erba 1106 elemental analyzer. The IR spectra were recorded in the $4000-400 \mathrm{~cm}^{-1}$ region with a Nicolet FT-VERTEX 


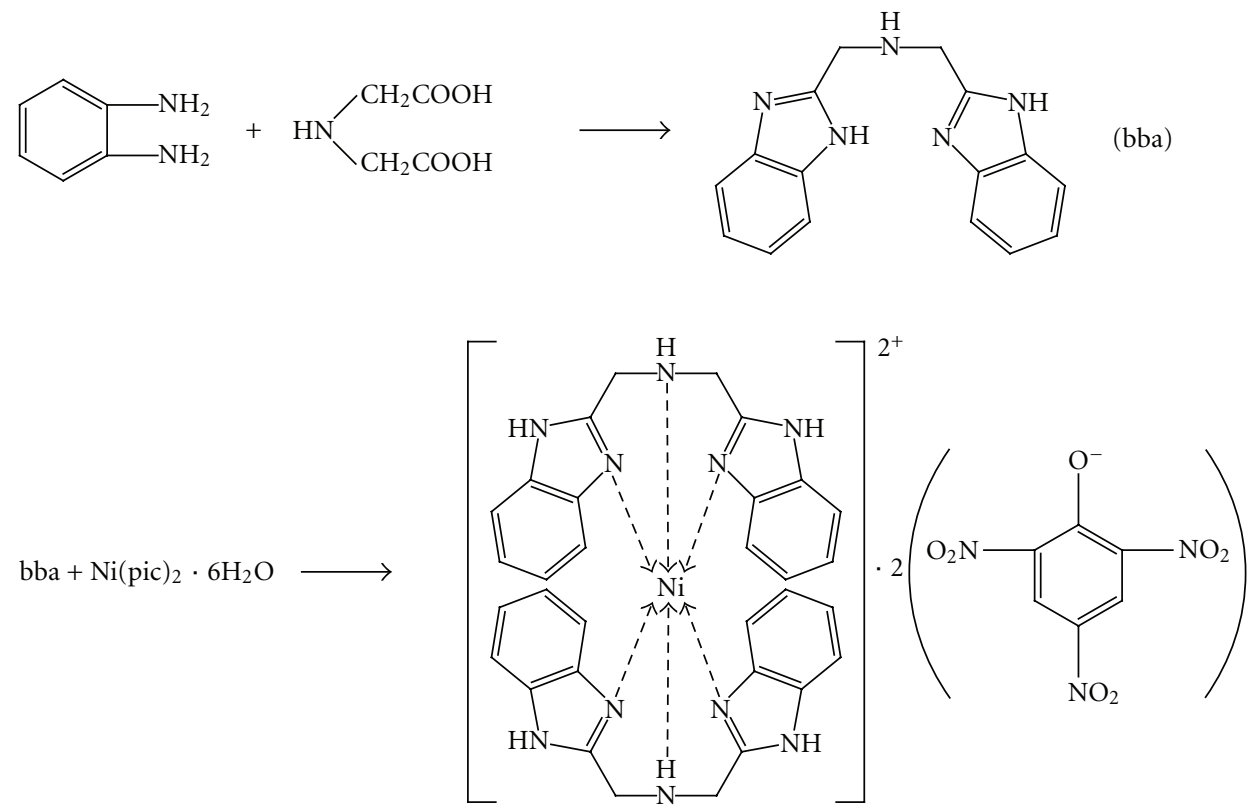

Scheme 1: The synthesis of ligand bba and its $\mathrm{Ni}(\mathrm{II})$ complex.

70 spectrometer using $\mathrm{KBr}$ pellets. Electronic spectra were taken on a Lab-Tech UV Bluestar spectrophotometer. The fluorescence spectra were recorded on a 970-CRT spectrofluorophotometer. ${ }^{1} \mathrm{HNMR}$ spectra were obtained with a Mercury plus $400 \mathrm{MHz}$ NMR spectrometer with TMS as internal standard and DMSO- $d_{6}$ as solvent. Electrolytic conductance measurements were made with a DDS-11A type conductivity bridge using a $10^{-3} \mathrm{~mol} \cdot \mathrm{L}^{-1}$ solution in DMF at room temperature.

2.2. Electronic Absorption Spectra. Absorption titration experiment was performed with fixed concentrations of the complexes while gradually increasing concentration of CTDNA. While measuring the absorption spectra, a proper amount of CT-DNA was added to both compound solution and the reference solution to eliminate the absorbance of CTDNA itself. From the absorption titration data, the binding constant $\left(K_{b}\right)$ was determined using [17]

$$
\frac{[\mathrm{DNA}]}{\varepsilon_{a}-\varepsilon_{f}}=\frac{[\mathrm{DNA}]}{\varepsilon_{b}-\varepsilon_{f}}+\frac{1}{K_{b}\left(\varepsilon_{b}-\varepsilon_{f}\right)},
$$

where [DNA] is the concentration of DNA in base pairs, the apparent absorption coefficient, $\varepsilon_{a}, \varepsilon_{f}$, and $\varepsilon_{b}$ correspond to $A_{\text {obsd }} /[M]$, the extinction coefficient of the free compounds and the extinction coefficient of the compound when fully bound to DNA, respectively. In plots of [DNA] $/\left(\varepsilon_{a}-\varepsilon_{f}\right)$ versus [DNA], $K_{b}$ is given by the ratio of slope to the intercept.

2.3. Fluorescence Spectra. EB emits intense fluoresence in the presence of CT-DNA due to its strong intercalation between the adjacent CT-DNA base pairs. It was previously reported that the enhanced fluorescence can be quenched by the addition of a second molecule [18]. The extent of fluorescence quenching of EB bound to CT-DNA can be used to determine the extent of binding between the second molecule and CT-DNA. The competitive binding experiments were carried out in the buffer by keeping $[\mathrm{DNA}] /[\mathrm{EB}]=1$ and varying the concentrations of the compounds. The fluorescence spectra of EB were measured using an excitation wavelength of $520 \mathrm{~nm}$ and the emission range was set between 550 and $750 \mathrm{~nm}$. The spectra were analyzed according to the classical Stern-Volmer equation [19],

$$
\frac{I_{0}}{I}=1+K_{\mathrm{sv}}[Q]
$$

where $I_{0}$ and $I$ are the fluorescence intensities at $599 \mathrm{~nm}$ in the absence and presence of the quencher, respectively, $K_{\mathrm{sv}}$ is the linear Stern-Volmer quenching constant, [Q] is the concentration of the quencher.

2.4. Viscosity Measurements. Viscosity experiments were conducted on an Ubbelohde viscometer, immersed in a thermostated water-bath maintained at $25.0 \pm 0.1^{\circ} \mathrm{C}$. DNA samples approximately $200 \mathrm{bp}$ in average length were prepared by sonicating in order to minimize complexities arising from DNA flexibility [20]. Titrations were performed for the compounds $(3 \mathrm{mM})$, and each compound was introduced into the CT-DNA solution $(50 \mu \mathrm{M})$ present in the viscometer. Data were presented as $\left(\eta-\eta_{0}\right)^{1 / 3}$ versus the ratio of the concentration of the compound to CT-DNA, where $\eta$ is the viscosity of CT-DNA in the presence of the complex, and $\eta_{0}$ is the viscosity of CT-DNA alone. Viscosity values were calculated from the observed flow time of CT-DNA containing solutions corrected from the flow time of buffer alone $\left(t_{0}\right), \eta=\left(t-t_{0}\right) / t_{0}$. 
2.5. Synthesis. The synthetic route for the ligand bba and its $\mathrm{Ni}$ (II) complex are shown in Scheme 1.

2.5.1. Bis(2-benzimidazolymethyl)amine (bba). The ligand bba was synthesized according to the procedure reported by Berends and Stephan [21]. The infrared spectra and UV spectra of the bba were almost consistent with the literature. Elemental analysis: $\mathrm{C}_{16} \mathrm{H}_{15} \mathrm{~N}_{5}\left(\mathrm{Mr}=277.33 \mathrm{~g} \cdot \mathrm{mol}^{-1}\right)$ calcd: C 69.30; H 5.45; N 25.26\%; found: C 69.35; H 5.47; N $25.16 \%$. IR (KBr, pellet, $\left.\mathrm{cm}^{-1}\right)$ : $1270 \mathrm{~s}\left(\nu_{\mathrm{C}-\mathrm{N}}\right), 1620 \mathrm{~s}\left(\nu_{\mathrm{C}=\mathrm{N}}\right)$, UV-vis $(\lambda, \mathrm{nm}): 277,283, \varepsilon_{277}=5.99 \times 10^{2} \mathrm{~L} \cdot \mathrm{mol}^{-1} \cdot \mathrm{cm}^{-1}$, $\varepsilon_{283}=5.73 \times 10^{2} \mathrm{~L} \cdot \mathrm{mol}^{-1} \cdot \mathrm{cm}^{-1} \cdot{ }^{1} \mathrm{HNMR}$ (DMSO- $d_{6}$, $300 \mathrm{MHz}) \delta: 12.3(1 \mathrm{H}, \mathrm{N}-\mathrm{H}) ; 7.144(\mathrm{~m}, 4 \mathrm{H}) ; 7.5$ (d, 4H); 4.0 $(\mathrm{s}, 4 \mathrm{H}) \cdot \Lambda_{\mathrm{M}}(\mathrm{DMF}, 297 \mathrm{~K}): 1.29 \mathrm{~S} \cdot \mathrm{cm}^{2} \cdot \mathrm{mol}^{-1}$.

2.5.2. $\left[\mathrm{Ni}(\mathrm{bba})_{2}\right](\mathrm{pic})_{2} \cdot 3 \mathrm{MeOH}$. The ligand bba $(0.4 \mathrm{mmol})$ and $\mathrm{Ni}(\mathrm{II})$ picrate $(0.2 \mathrm{mmol})$ were dissolved in methanol $(15 \mathrm{~mL})$. A blue-green crystalline product which formed rapidly was filtered off, washed with methanol and absolute $\mathrm{Et}_{2} \mathrm{O}$, and dried in vacuo. The dried precipitate was dissolved in DMF resulting in a blue-green solution that was allowed to evaporate at room temperature. Blue-green crystals suitable for $\mathrm{X}$-ray diffraction studies were obtained after one week. $\mathrm{C}_{47} \mathrm{H}_{36} \mathrm{~N}_{16} \mathrm{Ni} \mathrm{O}_{17}\left(\mathrm{Mr}=1155.63 \mathrm{~g} \cdot \mathrm{mol}^{-1}\right)$ calcd: C 48.85; H 3.14; N 19.39\%; found: C 48.79; H 3.16; N 19.53\%. IR ( $\mathrm{KBr}$, pellet, $\left.\mathrm{cm}^{-1}\right)$ : $1272 \mathrm{~s}\left(\nu_{\mathrm{C}-\mathrm{N}}\right)$, $1434\left(\nu_{\mathrm{C}=\mathrm{N}-\mathrm{C}=\mathrm{C}}\right), 1487 \mathrm{~s}\left(\nu_{\mathrm{C}=\mathrm{N}}\right)$, UV-vis $(\lambda, \mathrm{nm}): 275$, 280, 407, $\varepsilon_{275}=6.55 \times 10^{2} \mathrm{~L} \cdot \mathrm{mol}^{-1} \cdot \mathrm{cm}^{-1}, \varepsilon_{280}=6.50 \times$ $10^{2} \mathrm{~L} \cdot \mathrm{mol}^{-1} \cdot \mathrm{cm}^{-1}, \varepsilon_{407}=7.99 \times 10^{2} \mathrm{~L} \cdot \mathrm{mol}^{-1} \cdot \mathrm{cm}^{-1} \cdot \Lambda_{\mathrm{M}}$ (DMF, $297 \mathrm{~K}): 128.5 \mathrm{~S} \cdot \mathrm{cm}^{2} \cdot \mathrm{mol}^{-1}$.

2.6. Crystal Structure Determination. A suitable single crystal was mounted on a glass fiber and the intensity data were collected on a Bruker Smart CCD diffractometer with graphite-monochromated Mo K $\alpha$ radiation $(\lambda=0.71073 \AA)$ at $296 \mathrm{~K}$. Data reduction and cell refinement were performed using the SMART and SAINT programs [22]. The structure was solved by direct methods and refined by full-matrix least squares against $F^{2}$ of data using SHELXTL software [23]. All $\mathrm{H}$ atoms were found in different electron maps and were subsequently refined in a riding-model approximation with $\mathrm{C}-\mathrm{H}$ distances ranging from 0.95 to $0.99 \AA$. Basic crystal data, description of the diffraction experiment, and details of the structure refinement are given in Table 1.

\section{Results and Discussion}

The ligand bba and its $\mathrm{Ni}(\mathrm{II})$ complex are very stable in the air. They are remarkably soluble in polar solvents such as DMF, DMSO, and $\mathrm{MeCN}$; slightly soluble in ethanol, methanol, ethyl acetate, and chloroform. The molar conductivities in DMF solution indicate that bba $\left(1.29 \mathrm{~S} \cdot \mathrm{cm}^{2} \cdot \mathrm{mol}^{-1}\right)$ is nonelectrolyte compound and its $\mathrm{Ni}(\mathrm{II})$ complex is $1: 2$ electrolyte compound [24].

3.1. Spectral Characterization. In the bba ligand, a strong band is found at ca. $1270 \mathrm{~cm}^{-1}$ together along with a broad band at $1436 \mathrm{~cm}^{-1}$. By analogy with the assigned bands of
TABLE 1: Crystallographic data and data collection parameters for the $\mathrm{Ni}(\mathrm{II})$ complex.

\begin{tabular}{|c|c|}
\hline Complex & {$\left[\mathrm{Ni}(\mathrm{bba})_{2}\right](\mathrm{pic})_{2} \cdot 3 \mathrm{MeOH}$} \\
\hline Molecular formula & $\mathrm{C}_{47} \mathrm{H}_{36} \mathrm{~N}_{16} \mathrm{NiO}_{17}$ \\
\hline Molecular weight & 1155.63 \\
\hline Crystal system & Triclinic \\
\hline Space group & P-1 \\
\hline $\mathrm{a}(\AA)$ & $10.4758(9)$ \\
\hline $\mathrm{b}(\AA)$ & $16.1097(13)$ \\
\hline$c(\AA)$ & $17.2302(14)$ \\
\hline$\alpha\left({ }^{\circ}\right)$ & $107.5590(10)$ \\
\hline$\beta\left({ }^{\circ}\right)$ & $107.5880(10)$ \\
\hline$\gamma\left({ }^{\circ}\right)$ & $96.9150(10)$ \\
\hline$V\left(\AA^{3}\right)$ & $2570.1(4)$ \\
\hline$Z$ & 2 \\
\hline$\rho_{\text {cald }}\left(\mathrm{mg} \mathrm{m}^{-3}\right)$ & 1.493 \\
\hline Absorption coefficient $\left(\mathrm{mm}^{-1}\right)$ & 0.467 \\
\hline$F(000)$ & 1188 \\
\hline Crystal size (mm) & $0.41 \times 0.38 \times 0.31$ \\
\hline$\theta$ range for data collection $\left({ }^{\circ}\right)$ & $2.04-25.00$ \\
\hline$h / k / l(\max , \min )$ & $-12,12 /-16,19 /-20,20$ \\
\hline Reflections collected & 18579 \\
\hline Independent reflections & $8974[R($ int $)=0.0203]$ \\
\hline Data/restraints/parameters & $8974 / 6 / 746$ \\
\hline Goodness-of-fit on $F^{2}$ & 1.097 \\
\hline Final $R_{1}, w R_{2}$ indices $[I>2 \sigma(I)]$ & $0.0383,0.1135$ \\
\hline$R_{1}, w R_{2}$ indices (all data) & $0.0466,0.1194$ \\
\hline Largest differences peak and hole $\left(\mathrm{e} \AA^{-3}\right)$ & 0.734 and -0.384 \\
\hline
\end{tabular}

imidazole, the former can be attributed to $\nu(\mathrm{C}=\mathrm{N}-\mathrm{C}=\mathrm{C})$, while the latter can be attributed to $v(\mathrm{C}=\mathrm{N})$ [25-27]. One of them shift to the higher frequency by around $41 \mathrm{~cm}^{-1}$ in the complex, which implies direct coordination of all three imine nitrogen atoms to metal ions. This is the preferred nitrogen atom for coordination as found for other metal complexes with benzimidazoles [28]. Information regarding the possible bonding modes of the picrate and benzimidazole rings may also be obtained from the IR spectra, such as 709, $744,1272,1363,1434,1487$, and $1633 \mathrm{~cm}^{-1}$ [29]. This fact agrees with the result determined by X-ray diffraction.

DMF solutions of ligand bba and its complexes show, as expected, almost identical UV spectra. The UV bands of bba $(275,280 \mathrm{~nm})$ are only marginally blue shifted $(1-2 \mathrm{~nm})$ in the complexes, which is clear evidence of $\mathrm{C}=\mathrm{N}$ coordination to the metal ions center. The absorption bands are assigned to $\pi \rightarrow \pi^{*}$ (imidazole) transitions. The bands of picrate $(407 \mathrm{~nm})$ are assigned to $\pi \rightarrow \pi^{*}$ transitions.

3.2. Crystal Structure of $\left[\mathrm{Ni}(\mathrm{bba})_{2}\right](\mathrm{pic})_{2} \cdot 3 \mathrm{MeOH}$. The molecular structure of the $\mathrm{Ni}(\mathrm{II})$ complex is shown in Figure 1, selected bond lengths and angles are summarized in Table 2. The $\mathrm{Ni}(\mathrm{II})$ atom is six-coordinate with a $\mathrm{NiN}_{4} \mathrm{O}_{2}$ environment. The bba ligand acts as a tridentate $\mathrm{N}$-donor and O-donor. The coordination geometry of the $\mathrm{Ni}(\mathrm{II})$ 


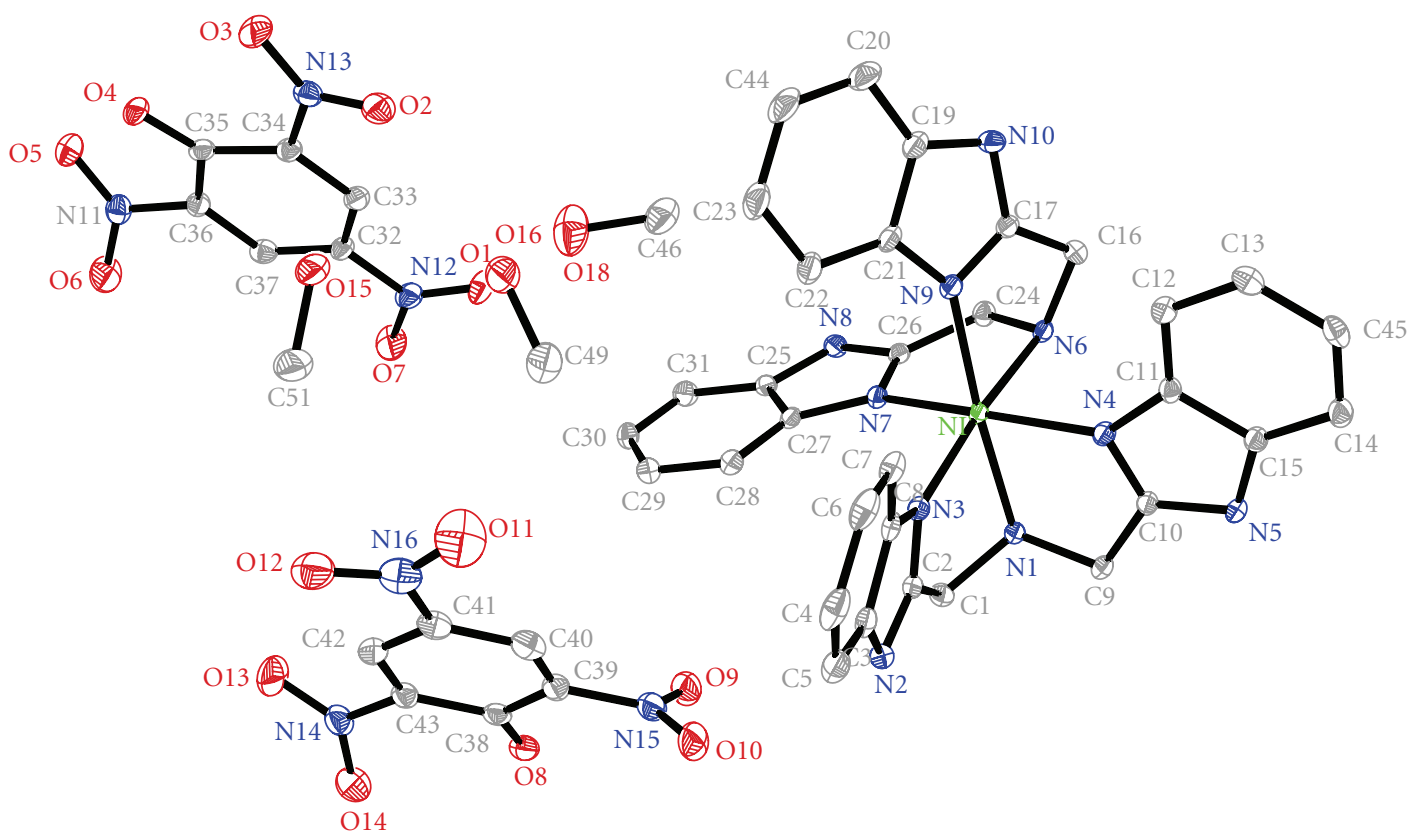

FIGURE 1: The molecular structure of the Ni(II) complex showing displacement ellipsoids at the $30 \%$ probability level. Hydrogen atoms have been omitted for clarity.

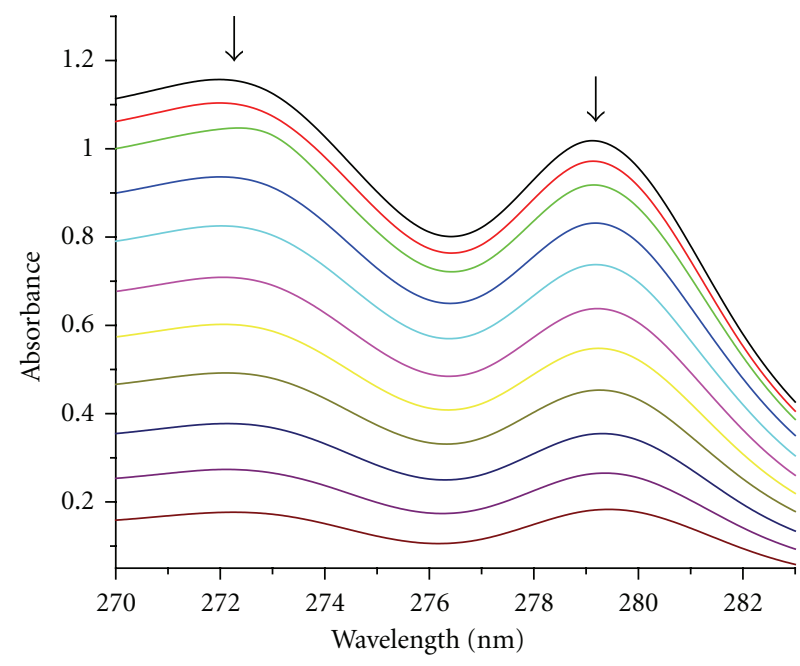

(a)

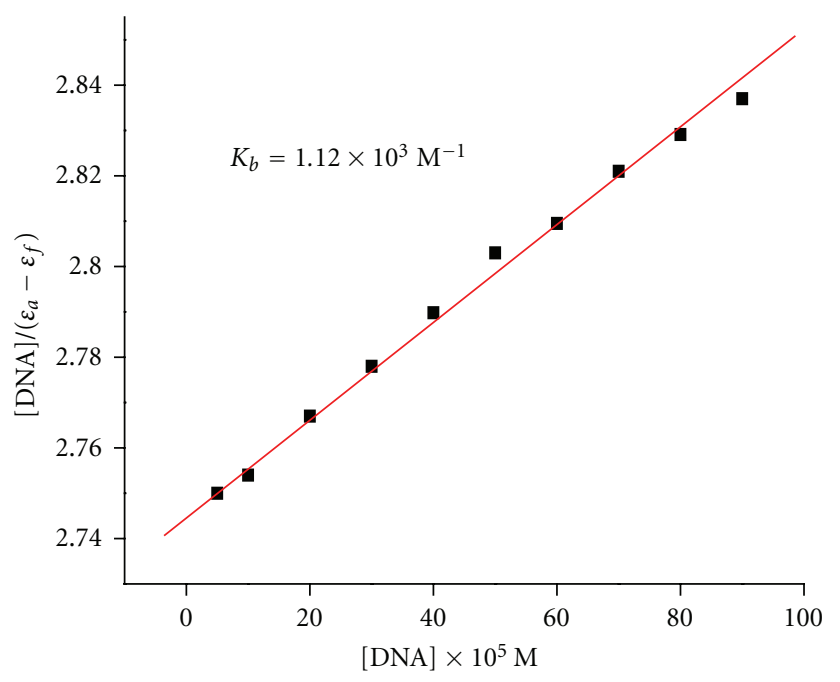

(b)

Figure 2: Electronic spectra of the Ni(II) complex $(30 \mu \mathrm{M})$ in the presence of $0,5,10,20,30,40,50,60,70,80$, and $90 \mu \mathrm{L}$ CT-DNA. [DNA] $=2.5 \times 10^{-5} \mathrm{M}$. Arrow shows the absorbance changes upon increasing CT-DNA concentration. Plots of [DNA]/( $\left.\varepsilon_{a}-\varepsilon_{f}\right)$ versus $[\mathrm{DNA}]$ for the titration of the $\mathrm{Ni}(\mathrm{II})$ complex with CT-DNA.

TABLE 2: Selected bond lengths $(\AA)$ and angles (deg) of the Ni(II) complex.

\begin{tabular}{|c|c|c|c|c|c|}
\hline \multicolumn{6}{|l|}{ Bond lengths } \\
\hline $\mathrm{Ni}-\mathrm{N}(1)$ & $2.1647(19)$ & $\mathrm{Ni}-\mathrm{N}(4)$ & $2.0793(18)$ & $\mathrm{Ni}-\mathrm{N}(6)$ & $2.1788(19)$ \\
\hline $\mathrm{Ni}-\mathrm{N}(3)$ & $2.0899(19)$ & $\mathrm{Ni}-\mathrm{N}(7)$ & $2.0667(18)$ & $\mathrm{Ni}-\mathrm{N}(9)$ & $2.0628(19)$ \\
\hline \multicolumn{6}{|l|}{ Bond angles } \\
\hline $\mathrm{N}(1)-\mathrm{Ni}-\mathrm{N}(6)$ & $94.12(7)$ & $\mathrm{N}(9)-\mathrm{Ni}-\mathrm{N}(7)$ & $173.40(7)$ & $\mathrm{N}(9)-\mathrm{Ni}-\mathrm{N}(4)$ & $98.11(7)$ \\
\hline $\mathrm{N}(3)-\mathrm{Ni}-\mathrm{N}(7)$ & $173.40(7)$ & $\mathrm{N}(3)-\mathrm{Ni}-\mathrm{N}(1)$ & $79.29(7)$ & $\mathrm{N}(7)-\mathrm{Ni}-\mathrm{N}(4)$ & $166.55(7)$ \\
\hline $\mathrm{N}(9)-\mathrm{Ni}-\mathrm{N}(3)$ & $107.52(7)$ & $\mathrm{N}(7)-\mathrm{Ni}-\mathrm{N}(3)$ & $98.95(7)$ & $\mathrm{N}(3)-\mathrm{Ni}-\mathrm{N}(4)$ & $89.98(7)$ \\
\hline $\mathrm{N}(1)-\mathrm{Ni}-\mathrm{N}(9)$ & $173.19(7)$ & $\mathrm{N}(7)-\mathrm{Ni}-\mathrm{N}(1)$ & $90.23(7)$ & $\mathrm{N}(1)-\mathrm{Ni}-\mathrm{N}(4)$ & $81.52(7)$ \\
\hline $\mathrm{N}(9)-\mathrm{Ni}-\mathrm{N}(6)$ & $79.07(8)$ & $\mathrm{N}(7)-\mathrm{Ni}-\mathrm{N}(6)$ & $81.11(7)$ & $\mathrm{N}(4)-\mathrm{Ni}-\mathrm{N}(6)$ & $88.87(7)$ \\
\hline
\end{tabular}




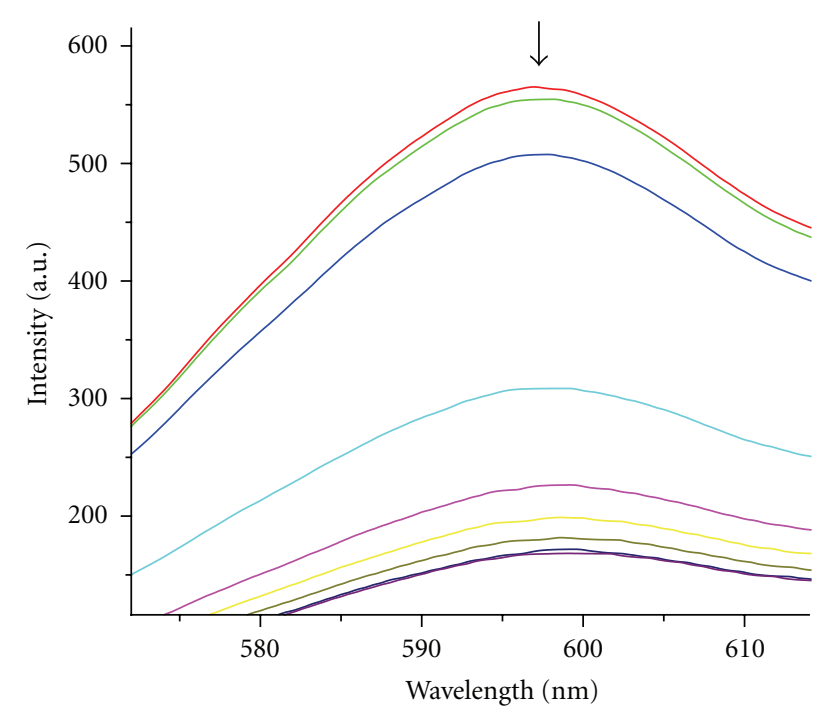

(a)

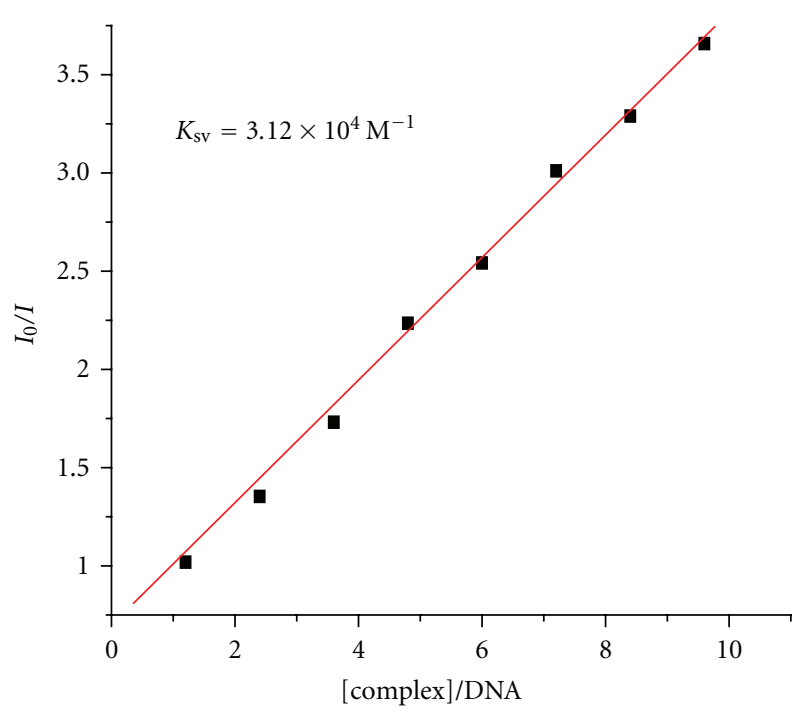

(b)

FIgURE 3: Emission spectra of EB bound to DNA in the presence of the complex. [Complex] $=3 \times 10^{-3} \mathrm{M} ; \lambda_{\mathrm{ex}}=520 \mathrm{~nm}$. The arrow shows the intensity changes upon increasing concentrations of the complex. Fluorescence quenching curves of EB bound to CT-DNA by the Ni(II) complex. (Plots of $I_{0} / I$ versus [Complex]/DNA.).

may be best described as distorted octahedral with four coordination nitrogen atoms from an ideal equatorial plane. The maximum deviation (N9) from the plane containing these four $\mathrm{N}$ atoms is $0.764 \AA$. The bond average length between the $\mathrm{Ni}$ ion and the apical $\mathrm{N}$ atom $(\mathrm{N} 1, \mathrm{~N} 6)$ is $2.171 \AA$, which is about $0.097 \AA$ longer than the bond average length between the $\mathrm{Ni}$ ion and four coordination $\mathrm{N}$ atoms from an equatorial plane. This geometry is assumed by the $\mathrm{Ni}(\mathrm{II})$ to relieve the steric crowding. Therefore, compared with a regular octahedron, it reflects a relatively distorted coordination octahedron around $\mathrm{Ni}(\mathrm{II})$.

\subsection{Spectral Studies of the Interactions with DNA}

3.3.1. Electronic Absorption Titration. Electronic absorption spectroscopy is universally employed to determine the binding characteristics of metal complexes with DNA [30-32]. The absorption spectra of the $\mathrm{Ni}$ (II) complex in the absence and presence of CT-DNA are given in Figure 2. There are two well-resolved bands at about 272, $278 \mathrm{~nm}$ for the complex. The $\lambda$ for the ligand increases only from 272 to 273 , and for the complex from 278 to $279 \mathrm{~nm}$, a slight red shift about $1 \mathrm{~nm}$ under identical experimental conditions. The slight red shift suggests that the $\mathrm{Ni}(\mathrm{II})$ complex interacts with DNA [33].

The binding constant $K_{b}$ for the complex has been determined from the plot of [DNA]/( $\left.\varepsilon_{a}-\varepsilon_{f}\right)$ versus [DNA] and was found to be $1.12 \times 10^{3} \mathrm{M}^{-1}$. Compared with those of the so-called DNA-intercalative ruthenium complexes $(1.1 \times$ $\left.10^{4}-4.8 \times 10^{4} \mathrm{M}^{-1}\right)$ [34], the binding constants $\left(K_{b}\right)$ of the $\mathrm{Ni}(\mathrm{II})$ complex suggest that the complex with DNA with an affinity is less than the classical intercalators.

3.3.2. Fluorescence Spectroscopic Studies. intensity in the EBDNA adduct allows determination of the affinity of the

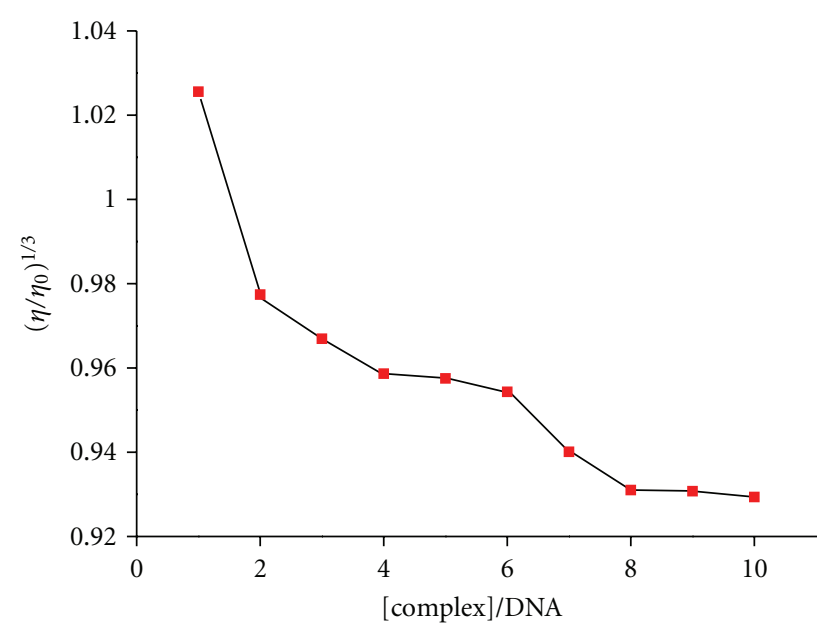

FIGURE 4: Effect of increasing amounts of the Ni(II) complex on the relative viscosity of CT-DNA at $25.0 \pm 0.1^{\circ} \mathrm{C}$.

complex for DNA, whatever the binding mode may be. If a complex can replace $\mathrm{EB}$ from DNA-bound $\mathrm{EB}$, the fluorescence of the solution will be quenched due to the fact that free EB molecules are readily quenched by the surrounding water molecules [35]. For all the compounds, no emission was observed either alone or in the presence of CT-DNA in the buffer. The fluorescence quenching of EB bound to CT-DNA by the $\mathrm{Ni}(\mathrm{II})$ complex is shown in Figure 3. The quenching of EB bound to CT-DNA by the $\mathrm{Ni}(\mathrm{II})$ complex is in good agreement with the linear SternVolmer equation, which provides further evidence that the $\mathrm{Ni}$ (II) complex bind to DNA. The quenching plots illustrate that the quenching of EB bound to DNA by the complex is in good agreement with the linear Stern-Volmer equation, which also proves that the complex binds to DNA. The $K_{\mathrm{sv}}$ 
value for the $\mathrm{Ni}$ (II) complex is $3.12 \times 10^{4} \mathrm{M}^{-1}$. The data suggest that the $\mathrm{Ni}(\mathrm{II})$ complex interacts with DNA.

3.3.3. Viscosity Studies. Optical photophysical techniques are widely used to study the binding model of the ligand, metal complexes, and DNA but not to give sufficient clues to support a binding model. Therefore, viscosity measurements were carried out to further clarify the interaction of metal complexes and DNA. Hydrodynamic measurements that are sensitive to the length change (i.e., viscosity and sedimentation) are regarded as the least ambiguous and the most critical tests of a binding model in solution in the absence of crystallographic structural data $[15,20]$. A classical intercalative mode causes a significant increase in viscosity of DNA solution due to increase in separation of base pairs at intercalation sites and hence an increase in overall DNA length. By contrast, complexes that bind exclusively in the DNA grooves by partial and/or nonclassical intercalation, under the same conditions, typically cause less pronounced (positive or negative) or no change in DNA solution viscosity [20]. The values of $\left(\eta-\eta_{0}\right)^{1 / 3}$ were plotted against [compound]/[DNA] (Figure 4). For the $\mathrm{Ni}(\mathrm{II})$ complex, as increasing the amounts of compound, the viscosity of DNA decreases steadily. The decreased relative viscosity of DNA may be explained by a binding mode which produced bends or kinks in the DNA and thus reduced its effective length and concomitantly its viscosity. The results suggest that the $\mathrm{Ni}(\mathrm{II})$ complex may bind to DNA by partial intercalation.

\section{Conclusions}

In this paper, a new $\mathrm{Ni}$ (II) complex has been synthesized and characterized. Moreover, the DNA-binding properties of the $\mathrm{Ni}$ (II) complex were investigated by electronic absorption, fluorescence, and viscosity measurements. The experimental results indicate that the $\mathrm{Ni}$ (II) complex can bind to CTDNA by partial intercalation mode. Information obtained from our study will be helpful to understand the mechanism of interactions of benzimidazoles and their complexes with nucleic acids and should be useful in the development of potential probes of DNA structure and conformation.

\section{Appendix}

\section{Additional Data}

CCDC 825141 contains the additional crystallographic data for this paper. These data can be obtained free of charge from The Cambridge Crystallographic Data Centre via http://www.ccdc.cam.ac.uk/data_request/cif.

\section{Acknowledgments}

The authors acknowledge the financial support and a grant from "Qing Lan" Talent Engineering Funds by Lanzhou Jiaotong University. The grant from "Long Yuan Qing Nian" of Gansu Province is also acknowledged.

\section{References}

[1] M. Mrksich and P. B. Dervan, "Antiparallel side-byside heterodimer for sequence-specific recognition in the minor groove of DNA by a distamycin/1-methylimidazole-2carboxamide-netropsin pair," Journal of the American Chemical Society, vol. 115, no. 7, pp. 2572-2576, 1993.

[2] C. Kokubo and T. Katsuki, "Highly enantioselective catalytic oxidation of alkyl aryl sulfides using Mn-salen catalyst," Tetrahedron, vol. 52, no. 44, pp. 13895-13900, 1996.

[3] S. Schoumacker, O. Hamelin, J. Pécaut, and M. Fontecave, "Catalytic asymmetric sulfoxidation by chiral manganese complexes: acetylacetonate anions as chirality switches," Inorganic Chemistry, vol. 42, no. 24, pp. 8110-8116, 2003.

[4] C. M. Dupureur and J. K. Barton, "Structural Studies of $\Lambda$ and $\Delta-\left[\mathrm{Ru}(\text { phen })_{2} \mathrm{dppz}\right]^{2+}$ Bound to d(GTCGAC) $)_{2}$ : characterization of Enantioselective Intercalation," Inorganic Chemistry, vol. 36, no. 1, pp. 33-43, 1997.

[5] C. Hemmert, M. Pitié, M. Renz, H. Gornitzka, S. Soulet, and B. Meunier, "Preparation, characterization and crystal structures of manganese(II), iron(III) and copper(II) complexes of the bis[di-1,1-(2-pyridyl)ethyl] amine (BDPEA) ligand; evaluation of their DNA cleavage activities," Journal of Biological Inorganic Chemistry, vol. 6, no. 1, pp. 14-22, 2001.

[6] V. S. Li, D. Choi, Z. Wang, L. S. Jimenez, M. Tang, and H. Kohn, "Role of the C-10 substituent in mitomycin C-1-DNA bonding," Journal of the American Chemical Society, vol. 118, no. 10, pp. 2326-2331, 1996.

[7] G. Zuber, J. C. Quada, and S. M. Hecht, "Sequence selective cleavage of a DNA octanucleotide by chlorinated bithiazoles and bleomycins," Journal of the American Chemical Society, vol. 120, no. 36, pp. 9368-9369, 1998.

[8] A. Gellis, H. Kovacic, N. Boufatah, and P. Vanelle, "Synthesis and cytotoxicity evaluation of some benzimidazole-4,7-diones as bioreductive anticancer agents," European Journal of Medicinal Chemistry, vol. 43, no. 9, pp. 1858-1864, 2008.

[9] Ö. Ö. Güven, T. Erdoğan, H. Göker, and S. Yildiz, "Synthesis and antimicrobial activity of some novel phenyl and benzimidazole substituted benzyl ethers," Bioorganic and Medicinal Chemistry Letters, vol. 17, no. 8, pp. 2233-2236, 2007.

[10] K. Kopańska, A. Najda, J. Zebrowska et al., "Synthesis and activity of $1 H$-benzimidazole and $1 H$-benzotriazole derivatives as inhibitors of Acanthamoeba castellanii," Bioorganic and Medicinal Chemistry, vol. 12, no. 10, pp. 2617-2624, 2004.

[11] K. C. Skyrianou, F. Perdih, I. Turel, D. P. Kessissoglou, and G. Psomas, "Nickel-quinolones interaction-part 2: interaction of nickel(II) with the antibacterial drug oxolinic acid," Journal of Inorganic Biochemistry, vol. 104, no. 2, pp. 161-170, 2010.

[12] K. C. Skyrianou, C. P. Raptopoulou, V. Psycharis, D. P. Kessissoglou, and G. Psomas, "Structure, cyclic voltammetry and DNA-binding properties of the bis(pyridine)bis(sparfloxacinato)nickel(II) complex," Polyhedron, vol. 28, no. 15, pp. 3265-3271, 2009.

[13] Y. Jin, M. A. Lewis, N. H. Gokhale, E. C. Long, and J. A. Cowan, "Influence of stereochemistry and redox potentials on the single- and double-strand DNA cleavage efficiency of $\mathrm{Cu}(\mathrm{II})$-and $\mathrm{Ni}(\mathrm{II}) \cdot$ Lys-Gly-his-derived ATCUN metallopeptides," Journal of the American Chemical Society, vol. 129, no. 26, pp. 8353-8361, 2007.

[14] F. Bisceglie, M. Baldini, M. Belicchi-Ferrari et al., "Metal complexes of retinoid derivatives with antiproliferative activity: synthesis, characterization and DNA interaction studies," European Journal of Medicinal Chemistry, vol. 42, no. 5, pp. 627-634, 2007. 
[15] J. B. Chaires, "Tris(phenanthroline)ruthenium(II) enantiomer interactions with DNA: mode and specificity of binding," Biochemistry, vol. 32, no. 10, pp. 2573-2584, 1993.

[16] J. Marmur, "A procedure for the isolation of deoxyribonucleic acid from microorganisms," Methods in Enzymology, vol. 6, pp. 726-738, 1963.

[17] A. Wolfe, G. H. Shimer, and T. Meehan, "Polycyclic aromatic hydrocarbons physically intercalate into duplex regions of denatured DNA," Biochemistry, vol. 26, no. 20, pp. 6392-6396, 1987.

[18] M. Chauhan, K. Banerjee, and F. Arjmand, "DNA binding studies of novel copper(II) complexes containing Ltryptophan as chiral auxiliary: in vitro antitumor activity of $\mathrm{Cu}-\mathrm{Sn}_{2}$ complex in human neuroblastoma cells," Inorganic Chemistry, vol. 46, no. 8, pp. 3072-3082, 2007.

[19] J. R. Lakowicz and G. Weber, "Quenching of fluorescence by oxygen. A probe for structural fluctuations in macromolecules," Biochemistry, vol. 12, no. 21, pp. 4161-4170, 1973.

[20] S. Satyanarayana, J. C. Dabrowiak, and J. B. Chaires, "Neither $\Delta$ - nor $\Lambda$-tris(phenanthroline)ruthenium(II) binds to DNA by classical intercalation," Biochemistry, vol. 31, no. 39, pp. 93199324, 1992.

[21] H. P. Berends and D. W. Stephan, "Copper(I) and copper(II) complexes of biologically relevant tridentate ligands," Inorganica Chimica Acta, vol. 93, no. 4, pp. 173-178, 1984.

[22] Bruker, Smart Saint and Sadabs, Bruker Axs, Inc., Madison, Wisc, USA, 2000.

[23] G. M. Sheldrick, SHELXTL, Siemmens Analytical X-Ray Instruments, Inc., Madison, Wisc, USA, 1996.

[24] W. J. Geary, "The use of conductivity measurements in organic solvents for the characterisation of coordination compounds," Coordination Chemistry Reviews, vol. 7, no. 1, pp. 81-122, 1971.

[25] C. Y. Su, B. S. Kang, C. X. Du, Q. C. Yang, and T. C. W. Mak, "Formation of mono-, bi-, tri-, and tetranuclear Ag(I) complexes of $C_{3}$-symmetric tripodal benzimidaxole ligands," Inorganic Chemistry, vol. 39, no. 21, pp. 4843-4849, 2000.

[26] R. J. Sundberg and R. B. Martin, "Interactions of histidine and other imidazole derivatives with transition metal ions in chemical and biological systems," Chemical Reviews, vol. 74, no. 4, pp. 471-517, 1974.

[27] V. McKee, M. Zvagulis, and C. A. Reed, "Further insight into magnetostructural correlations in binuclear copper(II) species related to methemocyanin: X-ray crystal structure of a 1,2$\mu$-nitrito complex," Inorganic Chemistry, vol. 24, no. 19, pp. 2914-2919, 1985.

[28] T. J. Lane, I. Nakagawa, J. L. Walter, and A. J. Kandathil, "Infrared investigation of certain imidazole derivatives and their metal chelates," Inorganic Chemistry, vol. 1, pp. 267-276, 1962.

[29] H. Wu, R. Yun, K. Li, K. Wang, X. Huang, and T. Sun, "Synthesis, crystal structure and spectra properties of the nickel (II) complex with 1,3-bis(1-benzylbenzimidazol2-yl)2-oxopropane," Synthesis and Reactivity in Inorganic, MetalOrganic and Nano-Metal Chemistry, vol. 39, no. 9, pp. 614617, 2009.

[30] H. Li, X. Y. Le, D. W. Pang, H. Deng, Z. H. Xu, and Z. H. Lin, "DNA-binding and cleavage studies of novel copper(II) complex with L-phenylalaninate and 1,4,8,9-tetraaza-triphenylene ligands," Journal of Inorganic Biochemistry, vol. 99, no. 11, pp. 2240-2247, 2005.

[31] V. G. Vaidyanathan and B. U. Nair, "Synthesis, characterization, and DNA binding studies of a chromium(III) complex containing a tridentate ligand," European Journal of Inorganic Chemistry, no. 19, pp. 3633-3638, 2003.

[32] V. G. Vaidyanathan and B. U. Nair, "Nucleobase oxidation of DNA by (terpyridyl)chromium(III) derivatives," European Journal of Inorganic Chemistry, no. 9, pp. 1840-1846, 2004.

[33] J. Liu, T. Zhang, T. Lu et al., "DNA-binding and cleavage studies of macrocyclic copper(II) complexes," Journal of Inorganic Biochemistry, vol. 91, no. 1, pp. 269-276, 2002.

[34] A. M. Pyle, J. P. Rehmann, R. Meshoyrer, C. V. Kumar, N. J. Turro, and J. K. Barton, "Mixed-ligand complexes of ruthenium(II): factors governing binding to DNA," Journal of the American Chemical Society, vol. 111, no. 8, pp. 3051-3058, 1989.

[35] B. C. Baguley and M. Le Bret, "Quenching of DNA-ethidium fluorescence by amsacrine and other antitumor agents: a possible electron-transfer effect," Biochemistry, vol. 23, no. 5, pp. 937-943, 1984. 


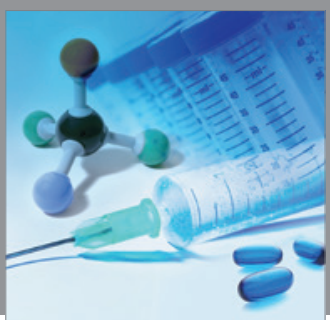

International Journal of

Medicinal Chemistry

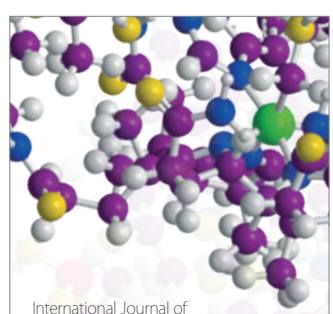

Carbohydrate Chemistry

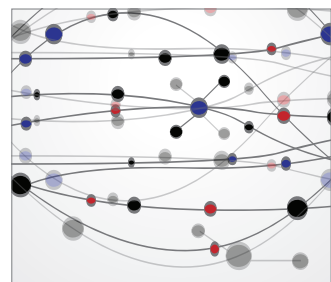

The Scientific World Journal
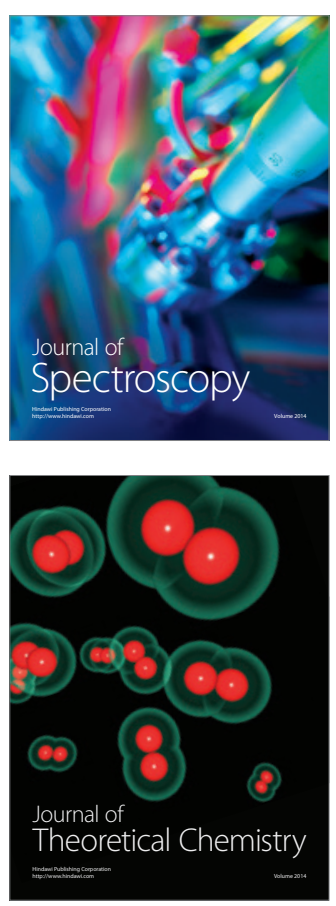
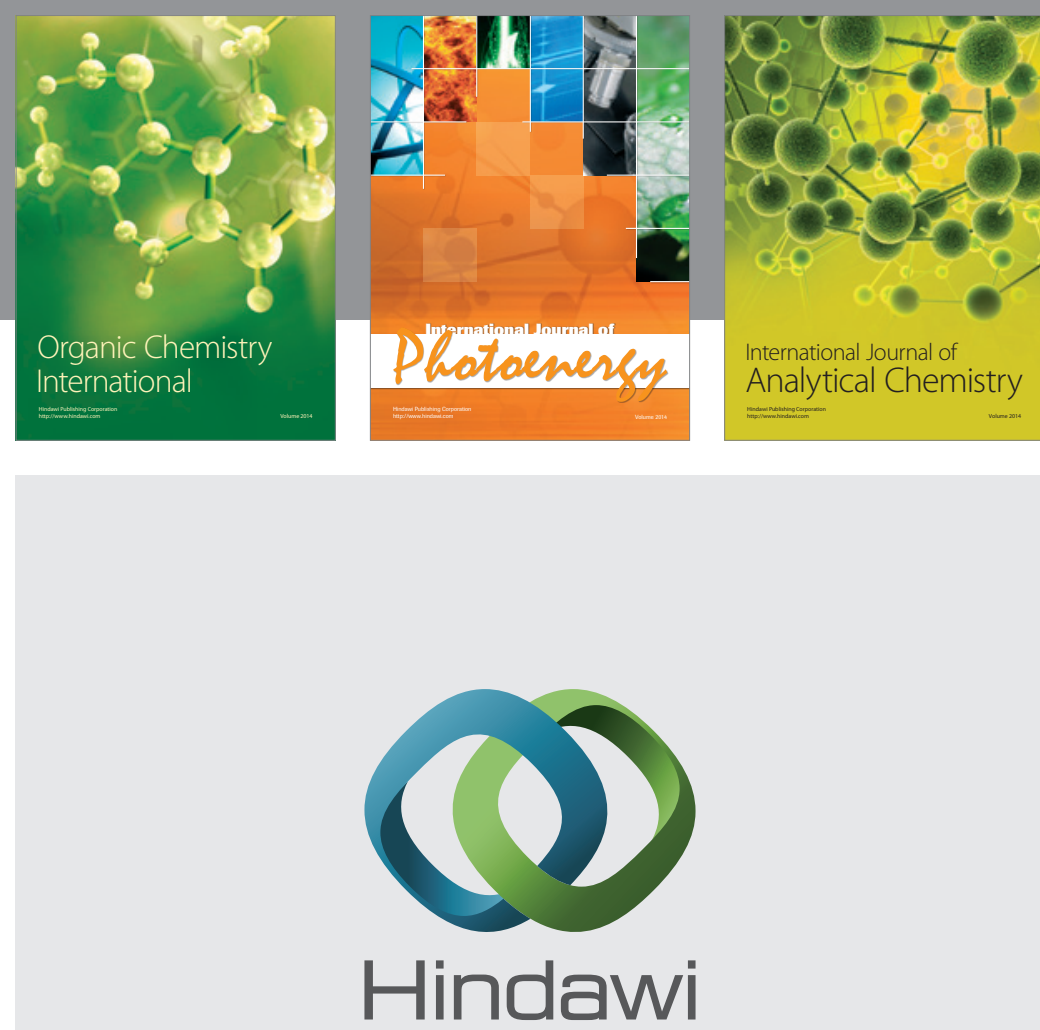

Submit your manuscripts at

http://www.hindawi.com
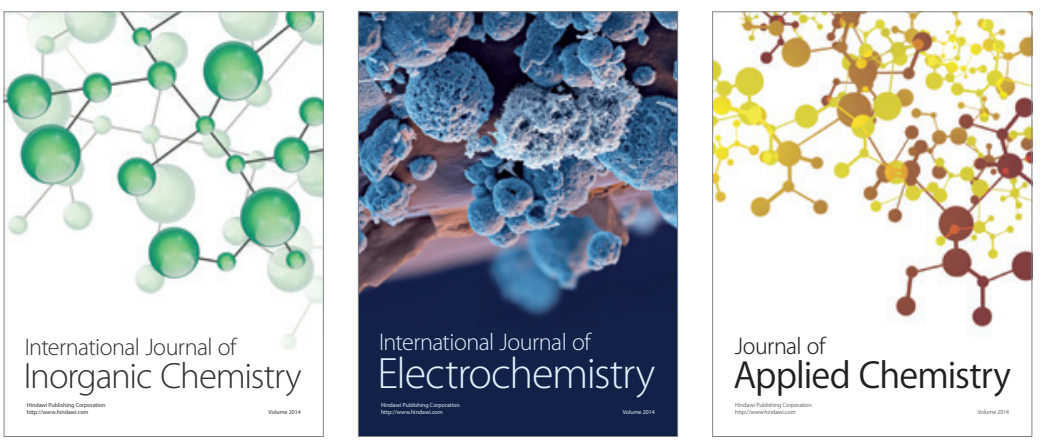

Journal of

Applied Chemistry
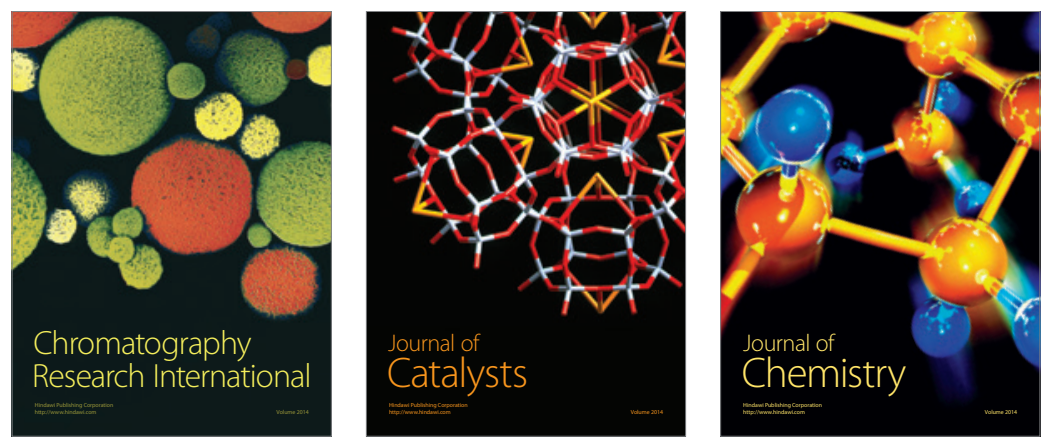
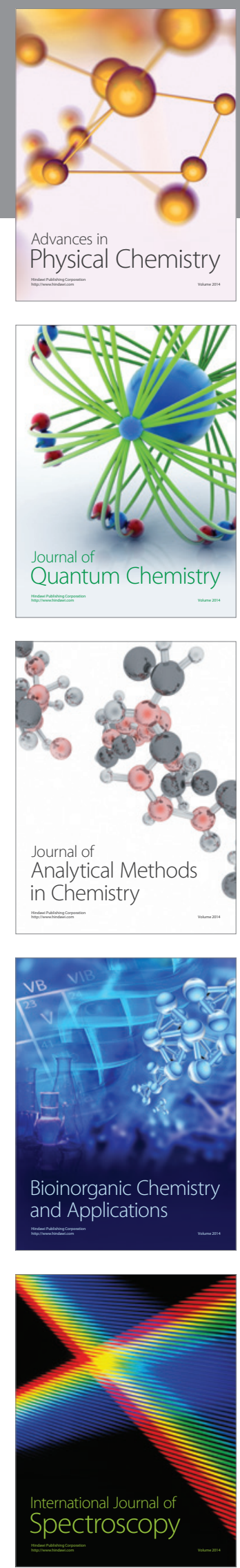